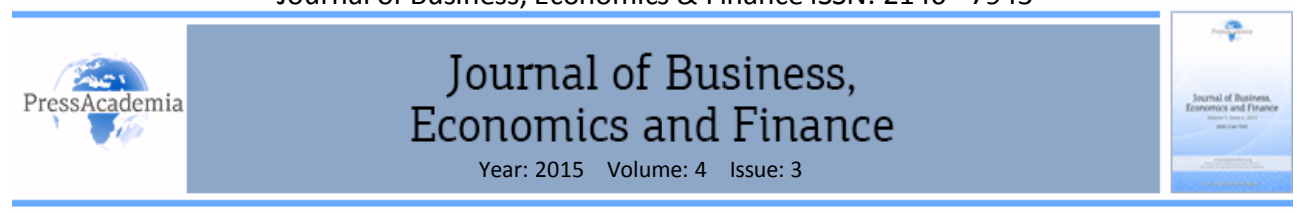

\title{
EFFECT OF BRAND EQUITY ON FIRMS' FINANCIAL PERFORMANCE IN CONSUMER GOODS INDUSTRIES
}

\section{DOI: 10.17261/Pressacademia.2105313056}

\section{Gokhan Aydin', Burc Ulengin²}

'Istanbul Arel University, Turkey. Email: gokhanaydin@arel.edu.tr

${ }^{2}$ Istanbul Technical University, Turkey. Email: ulenginbur@itu.edu.tr

\section{Keywords \\ Consumer based brand equity, brand equity, brand financial performance, CBBE}

\section{JEL Classification} M31, L25

\begin{abstract}
This study aims to find empirical evidence linking consumer based brand equity (CBBE) with financial performance of firms. Aaker's CBBE approach is adopted and this equity is measured using a questionnaire developed from scales in existing literature. Differing from the extant literature, this study relates CBBE and firms' performance by taking a direct approach in measuring financial performance by utilizing independently audited financial statements. A face-to-face survey study encompassing 28 companies from a variety of consumer goods industries was carried out in Turkey arriving at 505 valid responses. Firms' financial performance was assessed using ten different performance indicators derived from financial statements submitted to Istanbul Stock Exchange. Following an exploratory factor analysis to reveal CBBE dimensions, a multiple regression analysis was carried out to test potential effects of CBBE factors on financial performance indicators. As an outcome of the analysis it has been seen that the components of CBBE positively affect most of the financial performance indicators to varying extents. Perceived quality dimension appears to be the major driver of financial performance followed by the composite factor encompassing brand awareness and brand association components.
\end{abstract}

\section{INTRODUCTION}

The performance of a firm is intuitively expected to be improved as a result of a stronger brand and higher brand equity. However 'brand equity' is defined in many different ways and there is no generally accepted standard way of measuring it. In this study a consumer based perspective is adopted in examining the brand equity concept. Consumer based brand equity approaches adopt a cognitive psychological point of view in assessing the brand and the value created by it. Consumer based brand equity helps marketers in many ways as discussed in the following sections however it is a difficult task to relate it with financial performance. Consequently there are few empirical studies available in the existing literature that link consumer based brand equity and actual financial performance of firms creating a research gap in this important field.

Consumer based brand equity (CBBE) and its elements help customers in interpreting and processing information, create confidence in purchasing decisions and also enhance 
customers' satisfaction (Aaker 1991; Davis 2000; Ambler 2003). The familiarity, high quality and reliability offered by brands decrease the uncertainty and risk involved in consumers' decision making process. Moreover, a more subjective aspect of value is also obtained from brands by the consumers. These personal benefits can materialize as selfesteem, self-actualization, enjoyment, sense of accomplishment, reference group belonging or status demonstration. This subjective value is related to brand associations and also related to Keller's (1993) brand equity component, the brand image. Consumer based brand equity help companies increasing the efficiency and effectiveness of their marketing programs, enjoy higher profit margins (Erdem et al. 2002; Bendixen et.al. 2004), offers good trade leverage abd helps in implementing brand extensions (Aaker \& Keller 1990; Aaker 1991; Rangaswamy et al. 1993; Simon and Sullivan 1993). Additionally brand equity can also be used as a performance indicator for marketing activities in a company. Accountability and justification of marketing activities is an important and contemporary area of interest both for practitioners and academics in marketing (Christodoulides and de Chernatony 2010).

Shareholders and senior management are basically interested in increasing the financial performance of the firms. This can be done by creating sustainable competitive advantage among the competition. In terms of marketing management, one of the best tools available is the brand(s). This creates an increasing interest in branding especially in practitioners of the art. The ways to manage it properly to gain competitive advantage in the markets provides an important research area. This study was carried out to illustrate whether or not an observable link exists between consumer based brand equity, which can to a certain extent be managed by managers and the financial performance of firms, which is an absolute necessity that should be provided by the continuing operations of the firms. The type, strength and magnitude of possible relations between components of brand equity and financial performance indicators can lead to meaningful managerial implications.

The effect of CBBE on financial performance is partially analyzed by researchers, for instance Aaker and Jacobson (1994) found positive effect of quality perception and awareness on return on stocks and Mizik and Jacobson (2008) assesses the relationships between perceptual brand attributes differentiation, relevance, esteem, knowledge, energy) based on Y\&R's Brand Asset Valuator (BAV) model and financial performance indicators (stock return, sales, operating income).

What distinguishes this study on brand equity from the others is the methodology of bringing together the CBBE and actual financial performances of a wide selection of brands from consumer industries.

\section{THEORETICAL BACKGROUND}

\subsection{Brand and Brand Equity}

Brand concept became popular in the 1980s and branding research continues to be an important field of marketing. The "brand" in the previous century was a concept attached to a product; however currently it is more an individual form that is separate from 
(tangible/intangible) products. Without a brand, a product is just a commodity that only has functionality and is very easy to imitate or copy. With a brand, a product receives an identity, which is a promise that expectations of the customer will be met. Thus a brand is a strong tool and has a significant communicative and informative role both for the customers and the managers.

Brand equity which is in essence an added value, a benefit for firms and consumers that is created by the brand, has been the focus of both marketing professionals and academics since the early 1990s (Aaker, 1996; Keller, 1993). Different definitions for brand equity have been proposed so the methodologies developed for measuring brand equity are numerous. The brand equity approaches in the literature can be categorized in three different groups; financially oriented models, behaviorally oriented models and composite models (Zimmermann, 2001). The first wave of models that emerged during the 1980s were financially oriented and helped to assign a monetary value to brands, a necessity for increasing leverage in acquisitions and mergers that were becoming increasingly widespread. This financial brand equity is also named brand value as it attaches a monetary value to the brand. Nevertheless these models have not satisfied the needs of marketing professionals. Clearly defining brand equity from a consumer perspective, identifying its components and also providing related measures were critical features marketing professionals needed. Accordingly brand equity from a cognitive psychological point of view is adopted and CBBE concept and different assessment models that address marketers' needs were developed. The third wave of models, the commercial composite models are predominantly promoted by marketing and advertising agencies that take into account both CBBE and financial results. These composite models can put a price tag on brands and helps in taking into account the customer point of view so they became popular in application as well.

\subsection{Consumer Based Brand Equity}

Depending on the point of view of the researcher, consumer based brand equity (CBBE) can be defined diversely to incorporate distinct dimensions. For instance Farquhar (1989) defined brand equity as 'the value added by the brand to the product'. Another common definition can be given as "incremental utility or value added to a product by its brand name" (Srivastava and Shocker, 1991). Some other popular definitions worth mentioning are: "the difference between overall brand preference and multi-attributed preference based on objectively measured attribute levels" by Park and Srinivasan (1994); "incremental cash flows that accrue to the firm due to its investments in brands" (Simon and Sullivan, 1993); brand loyalty and image (Shocker and Weitz, 1988); 'a set of brand assets and liabilities linked to a brand, its name and symbol, that add to or subtract from the value provided by a product or service to a firm and or to that firm's customers' by Aaker (1991); and finally 'the differential effect of brand knowledge on consumer response to the marketing of the brand' (Keller, 1993).

Among these various definitions one of the best-known (and one of the most cited studies) in CBBE is of David A. Aaker's. Aaker (1991) has adopted a multi-dimensional approach in knowing, distinguishing and differentiating products and brands that consists of mental assets and liabilities. Aaker's approach proposes a model that has five different 
dimensions that affect the consumer based brand equity. These dimensions are; "brand loyalty", "brand awareness", "perceived quality", "brand associations" and "other brand assets". Many scholars used the CBBE approach and dimensions offered by Aaker in their studies such as Motameni and Shahrokhi (1998); Prasad and Dev (2000); Yoo and Donthu (2001), Pappu et al. (2005) and Buil et al. (2008). In this study, CBBE and its components are assessed and measured based on Aaker's popular approach.

\subsubsection{Brand Awareness}

Brand awareness is one of the major determinants of CBBE in existing literature (Aaker 1991, Kapferer 1991, Keller 1993, Agarwal and Rao 1996, Krishnan 1996, Mackay, 2001). Aaker (1991) identifies brand awareness similarly as the ability of a potential buyer to recognize or recall that a brand is a member of a certain category and offers a brand awareness pyramid that categorizes different awareness levels starting from bottom up; unaware of brand, brand recognition, brand recall and top of mind. Similar approaches are found elsewhere in literature and brand awareness is typically measured by recall or recognition (Rossiter and Percy 1987, Keller 1993). Recognition helps a brand to distinguish from others and provides an opportunity to be evaluated by consumers (Howard, 1998 p.30). Moreover awareness is a prerequisite that needs to be present in consumers' minds to develop brand associations (Washburn and Plank, 2002). Due to the high number of brands covered in this study, brand recognition is measured (instead of brand recall) to provide feasibility of application.

\subsubsection{Brand Associations}

Brand associations consist of all brand-related thoughts, feelings, perceptions, smells, colors, music, images, experiences, beliefs and attitudes (Kotler and Keller 2006, p. 188). Thus a brand association can be anything linked in memory to a brand (Aaker, 1991). Associations have been categorized in different ways by researchers but a dichotomous approach dividing them into product based associations and organization based associations is widespread (Aaker, 1991; Chen, 2001). Product specifications are the primary basis for product-related attribute associations and determine a consumer's fundamental understanding of what product means (Keller 1993). Product associations include functional attribute associations and non-functional associations (Chen, 2001). Functional attributes can be considered as tangible features of a branded product (Keller 1993, Hankinson and Cowking 1993, de Chernatony and McWilliam, 1989). While evaluating a brand, consumers link performance of functional attributes of a product to its brand (Lassar et al. 1995). This component of brand associations is named as the 'value dimension' by Aaker (1996), which is one of the three underlying factors of associations in his approach. Non-functional attributes on the other hand include all symbolic and intangible attributes (Aaker 1991, Keller 1993, Chen 2001) that meet consumers' needs for self-expression, self-esteem, social status indication (Keller 1993, Pitta and Katsanis 1995). Aaker (1996) considers this factor as the brand image dimension of associations. Organizational associations, the third dimension of associations named by Aaker (1996), are not related to any product but include corporate capability associations (related to company's ability and know-how in delivering its intended outputs), and corporate social responsibility associations (Chen, 2001). 


\subsubsection{Brand Loyalty}

Brand loyalty is a core dimension of the brand equity model proposed by Aaker (1991, p. 39) and is defined as the attachment that a customer has to a brand. Loyalty can be observed as behavioral or attitudinal loyalty (Kumar and Shah, 2006). Behavioral loyalty is linked to consumer behavior in the marketplace that can be indicated by number of repeated purchases (Keller, 1998) or commitment to repeatedly buy the brand as a primary choice even if there are marketing efforts promoting other brands (Oliver, 1997). Attitudinal loyalty on the other hand focuses on consumers' preference of a brand, and refers to consumers' psychological attachment level and also attitudinal advocacy towards the brand (Chaudhuri \& Holbrook, 2001). In this study an attitudinal loyalty approach is chosen and measurement is carried out via the scale utilized by Jones et. al. (2008) and Yoo and Donthu (2001) which was originally based on Beatty and Kahle's (1988) work.

\subsubsection{Perceived Quality}

Perceived quality is considered as a component of brand equity by various researchers (Kapferer 1991, Kamakura and Russell 1993, Martin and Brown 1991, Feldwick 1996) and it is one of the main components of the brand equity construct of Aaker $(1991,1996)$. Perceived quality can be defined as customers' judgment about a product's overall excellence or superiority that is different from objective quality (Zeithaml 1988, p.3). It is nearly impossible for consumers to objectively assess a products' quality, so they perceive a quality level that originate from numerous stimuli and information resources available to them. Consequently perceived quality is an intangible overall feeling about a brand and does not directly imply the actual quality of a product (Aaker, $1991 \mathrm{pp} .85-86$ ).

\subsection{Benefits of Brand Equity}

Brand equity and its constituents can be seen as important assets for brand owners as they provide various benefits to marketers (Davis, 2000; Ambler, 2003. The benefits of brand equity for the firms has been highlighted in the literature as follows; easier differentiation and positioning, increased efficiency and effectiveness of marketing and advertising programs, enjoying higher prices hence higher profit margins (Erdem et. al., 2002; Bendixen et. al., 2004), good trade leverage over suppliers and distributors, ability to implement brand extensions and create competitive advantage (Aaker \& Keller, 1990; Aaker, 1991; Bottomley and Doyle 1996; Rangaswamy et al., 1993; Simon \& Sullivan, 1993; Smith \& Park, 1992). It was also seen in different contexts that higher brand equity lead to higher purchase intentions (Chang \& Liu, 2009; Cobb-Walgren et al., 1995; Washburn \& Plank, 2002; Senthilnathan and Tharmi 2012). Keller and Lehmann (2003) indicated in their study on brand value chain that investments in marketing programs advertising can alter the consumers' brand awareness, associations, and attitudes towards the product/brands. These in turn lead to attachment and finally an intention to purchase. It is expected that in the long run, these positive transformations can lead to improved firm performance (Okazaki and Taylor, 2008).

All these aforementioned benefits of consumer based brand equity are expected to affect the success of the companies. Increasing performance and positioning itself in a better place should help the companies in improving their financial performance. This 
performance can be calculated using various indicators that focus on different aspects of the financial performance. Higher awareness and loyalty should provide a larger consumer base and better pricing than competitors. Higher perceived quality paves the way for premium pricing, which should lead to higher margins and better profitability. Higher awareness, positive associations and higher quality perceptions should help companies in finding the financial resources they require more easily, hence lead to higher financial leverage.

\subsection{Hypotheses}

In line with the expected relations between consumer based brand equity components and the financial performance indicators of the firms the following hypotheses are developed:

$H 1_{i}$ : Higher awareness (i.e. F1) is positively related to higher financial performance indicators for firms.

$\mathrm{H}_{2}$ : Better brand associations are positively related to higher financial performance indicators for firms.

$\mathrm{H}_{\mathrm{i}}$ : Higher brand loyalty is positively related to higher financial performance indicators for firms.

$\mathrm{H} 4_{\mathrm{i}}$ : Higher perceived quality is positively related to higher financial performance indicators for firms.

The term " $\mathrm{i}$ " is used to indicate each distinct financial indicator.

\section{DATA AND METHODOLOGY}

In this study consumer based brand equity's effects on actual financial performance of the firms is evaluated by using multiple regression analysis between CBBE components and financial performance indicators. The main hypothesis proposed can be summarized as follows:

$\mathrm{Hn}_{\mathrm{i}}: \mathrm{n}^{\text {th }}$ consumer based brand equity component have an effect on $\mathrm{i}^{\text {th }}$ financial performance indicator.

Each relationship between CBBE components and financial performance indicators were tested using hypotheses derived from this major hypothesis using the model presented as Equation-1. This equation summarizes the model employed in the study to test the hypotheses in its simplest form.

$$
Y_{i j}=\beta_{0}+\beta_{1} X_{1 J}+\ldots+\beta_{4} X_{1 J}{ }^{2}+\ldots+\beta_{6} X_{3}{ }^{2}+\beta_{7} X_{1} \cdot X_{2} . .+\beta_{m} X_{n} . X_{n-1}+\varepsilon_{j}(1)
$$

$Y_{i j} \quad:$ Financial performance indicator

$X_{1 \ldots n} \quad$ : CBBE component

$\beta_{m} \quad$ : CBBE regression coefficients

$\varepsilon_{\mathrm{n}} \quad:$ Error term

$i=1,2 \ldots \mathrm{n} ; j=1,2 \ldots \mathrm{n}$ 
where $i=$ financial indicator; $j=$ firm

The data collected through a survey study (via a questionnaire) was used to measure CBBE dimensions, namely; perceived quality, brand awareness, brand associations, brand loyalty. The financial performance of the firms in the study is assessed using indicators derived through their annual financial statements announced to the Borsa Istanbul (Istanbul Stock Exchange; ISE).

The measurement scale that was used in this study is based mainly on Yoo and Donthu's (2001) study, which was founded upon Aaker's (1991) approach. Yoo and Donthu's (2001) scale seems to have strengths in the context of this study due to different characteristics, such as:

- using samples from multiple cultures and validating the scale culturally;

- ease of use and parsimony;

- applicability in different industries;

- ability to measure brand equity on (individual) consumer level.

The questions in the original study were translated into the local language (Turkish) and were revised by three local marketing professors and the authors to ensure accurate meaning. Some of the questions that were linguistically and culturally not suitable were dropped and new ones are added after academic expert assessments.

To conclude, a total of 13 questions were prepared to measure the related dimensions of brand equity. Five point Likert scale ranging from "Totally Disagree" to "Totally Agree" is used in measuring CBBE constructs.

The study was constructed to be as comprehensive as possible industry-wise, and be able to reflect the overall consumer market in Turkey. Consequently firms selected for this study were from diverse industries that cater to consumer needs. Ten companies are retailers from various fields, five from food and beverages, four from building materials and remaining are from other consumer goods industries.

To obtain accurate, reliable and comparable financial data, only companies that are publicly traded in the Borsa Istanbul (ISE) thus audited by certified auditing firms are considered in this study. Moreover only firms that are headquartered in Turkey and active in the consumer markets are included in the study to be able to collect reliable CBBE data. Multinational firms were excluded as strong CBBE from global operations may create halo effects and lead to misleading results when relating CBBE to financial performance.

Furthermore, a basic level of awareness among the populace, being an umbrella brand, and being outside of the financial services sector were selected as filtering criteria. Banking and financial services sectors are not included in this study due to their unique balance sheets and unique financial performance indicators, which cannot be compared to firms from other industries. Taking into account applicability issues and available resources, a total of 28 firms were chosen for the study. 


\subsection{Sampling and Survey Administration}

Seven different versions of the questionnaire were developed and the respondents were asked to evaluate the items for four distinct brands in each version. To discourage direct comparisons between brand and possible halo effects, brands in each version were selected from distinct industries. Due to the repetitive process of answering the same questions for different brands, face to face interview was chosen as the implementation method of the questionnaire to overcome concerns over reliability of answers.

The survey was carried out in Istanbul, the commercial hub of Turkey by a professional (accredited) marketing research firm. Taking into account the wide range of firms in the study that cater to different needs and wants, a wide demographic distribution was targeted via quota sampling. Sample size was selected as 500 and adults of age 18 and up were interviewed. A total of 672 questionnaires were collected out of which 505 complete questionnaires were usable for analysis. Each individual in the sample answered questions for four different brands consequently the effective sample size is $2,020(505 \times 4)$ as 2,020 data sets were used in the analysis.

Basic demographics of the sample that are provided in Table 1 reflect a reasonably balanced distribution in terms of gender and age.

Table 1: Basic Sample Demographics

\begin{tabular}{lrllll}
\hline \multicolumn{4}{c}{ Demographic (Percent of Total Sample) } \\
\hline \multicolumn{1}{c}{ Age } & \multicolumn{3}{c}{ Education } & \multicolumn{3}{c}{ Gender } \\
$18-24$ & $24.00 \%$ & Elementary School Grad. & $36.80 \%$ & Men & $52.10 \%$ \\
$25-34$ & $32.50 \%$ & Mid. \& High School Grad. & $51.50 \%$ & Women & $47.90 \%$ \\
$35-49$ & $33.70 \%$ & University Grad. \& above & $11.70 \%$ & \\
$50+$ & $9.90 \%$ & & & \\
\hline
\end{tabular}

\subsection{Financial Performance Indicators}

Financial performance of the firms may be observed directly from their financial statements or indirectly by obtaining views of the managers on firm's financial performance. In the latter method, the indicators that reflect the extent of the fulfillment of financial goals, such as sales levels, market shares in target markets and profitability are assessed (Moorman and Rust, 1999). In this study a direct approach in assessing financial performance is adopted and financial performance is appraised using financial data published by the firms. Financial performance indicators that can reveal different aspects of financial performance of a company such as profitability, efficiency, size of operations, financial credibility were chosen and calculated using publicly available income statements and balance sheets of the firms (through ISE). The indicators for measuring the financial performance may be listed as follows: Return on share price (ROS), Firm Value/Book Value (FVBV), Price/Sales ratio (PS), Net profit margin (NPM), EBITDA/Net Sales Ratio (EBNS), Return on Assets (ROA), Operational Income (OI), Current Ratio (CR), Financial Leverage 
Ratio (FLR) Net Sales (NS), Market Value (MV). These well-known indicators provide the ability to compare firms in different industries.

\section{ANALYSIS \& RESULTS}

In the analysis stage we aimed to test Equation-1 using ordinary least squares regression however the correlation between CBBE items were high (condition index >30). Consequently an explanatory factor analysis was implemented to obtain brand equity components. Through this factor analysis, individual questions were combined into meaningful factors that can be considered as the major components of CBBE.

Three distinct (significant) factors, which can be seen in Table 2, have appeared as the outcome of the factor analysis. VARIMAX rotation method is used in the analysis so that the factors remain uncorrelated with one another. Almost $73 \%$ of the total variance is represented by the three factors. Bartlett's sphericity test for the three orthogonal factors was significant at $99.9 \%(p<0.001)$ level with KMO score of 0.94 and chi square of 17145 (with 91 degrees of freedom).

Table 2: Factor analysis rotated component matrix

\begin{tabular}{|c|c|c|c|c|}
\hline Item (Summarized) & F1 & $\mathbf{F 2}$ & F3 & Communal. \\
\hline Degree of Brand Knowledge & 0.613 & & & 0.422 \\
\hline $\begin{array}{l}\text { Recognize the brand easily amongst } \\
\text { competitors }\end{array}$ & 0.723 & & & 0.641 \\
\hline Remember the brands' logo/symbol easily & 0.845 & & & 0.779 \\
\hline Remember the brand properties easily & 0.853 & & & 0.808 \\
\hline Visualize the brand easily & 0.836 & & & 0.781 \\
\hline Has high quality products/services & & & 0.809 & 0.764 \\
\hline $\begin{array}{l}\text { Offers superior quality compared to } \\
\text { others }\end{array}$ & & & 0.765 & 0.773 \\
\hline Offers functional / practical products & 0.727 & & 0.774 & 0.727 \\
\hline Reliable, doesn't create problem & & & 0.767 & 0.732 \\
\hline Brand will be my first choice & & 0.586 & 0.544 & 0.731 \\
\hline $\begin{array}{l}\text { Don't buy another brand if the product I } \\
\text { search is available in this brand }\end{array}$ & & 0.690 & 0.413 & 0.741 \\
\hline $\begin{array}{l}\text { Buy this brand even if it more expensive } \\
\text { than others }\end{array}$ & & 0.833 & & 0.733 \\
\hline $\begin{array}{l}\text { Buy this brand even the properties of } \\
\text { another brand is the same with it }\end{array}$ & & 0.800 & & 0.748 \\
\hline $\begin{array}{l}\text { Buy the brand even if there is a brand as } \\
\text { good as it }\end{array}$ & & 0.817 & & 0.768 \\
\hline Variance explained by each factor & $25.3 \%$ & $23.9 \%$ & $23.6 \%$ & \\
\hline
\end{tabular}

Factor-1 (F1): The components of the first factor (F1) consist of items that relate to the brand awareness and brand associations. In this study we were able to use only major indicator questions for each brand equity component to measure CBBE dimensions. 
Consequently the limited number of questions aimed to reveal associations have not been able to establish this antecedent as an independent factor. As was seen in another similar study by Yoo and Donthu (2001) brand awareness and brand associations appear as one dimension in this study. Consequently this factor incorporates the consumers' awareness, degree of knowledge of a brand and the ability to remember the logo and properties of a brand. We named this factor 'Knowledge' factor for ease of commenting.

Factor-2 (F2): The components of the second factor relate to consumers' loyalty to the brand. Consequently this dimension is named 'Loyalty'.

Factor-3 (F3): The third factor in the study incorporates perceived overall functionality, quality, and reliability of the brands and their products. Consequently this third dimension is named 'Perceived Quality'.

\subsection{Effect of CBBE Factors on Financial Performance Indicators}

Each of the financial performance indicators underwent a multiple regression analysis with the CBBE factors. The relationships were tested using the Equation 2, which is a modified version of Equation 1 that incorporates the results of factor analysis.

$$
\begin{aligned}
& Y_{i j}=\beta_{0}+\beta_{1} F_{1 j}+\beta_{2} F_{2 j}+\beta_{3} F_{3 j}+\beta_{4} F_{1 j} \cdot F_{2 j}+\beta_{5} F_{1 j} \cdot F_{3 j}+\beta_{6} F_{2 j} \cdot F_{3 j}+\beta_{7} F_{1 j}{ }^{2}+\beta_{8} F_{2 j}{ }^{2}+\beta_{9} F_{3 j}{ }^{2}+\varepsilon_{j}{ }^{(2)} \\
& Y_{i j} \quad \text { : Financial performance indicator } \\
& F_{1 \ldots 3} \quad \text { : CBBE factors } \\
& \beta_{1 \ldots 9} \quad: \text { CBBE factor scores } \\
& \varepsilon_{j} \quad: \text { Error term } \\
& i=1,2 \ldots \mathrm{n} \\
& j=1,2 \ldots \mathrm{n} \\
& \text { where } i=\text { financial indicator; } j=\text { firm }
\end{aligned}
$$

Squares of the factors and their products (multiplications with each other) are also added to the multiple regression analysis to detect possible non-linear relationships.

After carrying out the multiple regression analysis 11 times for each financial performance indicator, statistically significant relations were identified. All of the relations between CBBE and financial indicators are presented in Appendix 1.

To better illustrate the analysis and interpretation processes an example is provided below. In this example effects of the three CBBE factors on EBITDA / Net Sales financial performance indicator are presented. Overall findings of the study are presented after this (example) analysis.

The relationship between CBBE factors and the financial performance indicator EBITDA / Net Sales (EBNS) is revealed in Table 3 and equation (3). Wald test is used and insignificant coefficients are dropped from the equation. As can be seen, EBNS ratio is affected from all CBBE factors. 
Table 3: Multiple Regression between brand equity factors and EBITDA / Net Sales

\begin{tabular}{lccccc}
\hline \multicolumn{1}{c}{ Coefficients } & B & Std.error & Std. coeff. beta & t-value & t-probability \\
\hline Constant & 0.005 & 0.023 & & 0.235 & 0.817 \\
F3 & 0.251 & 0.068 & 1.003 & 3.661 & 0.001 \\
F1XF1 & 0.294 & 0.075 & 0.640 & 3.916 & 0.001 \\
F2XF3 & 0.374 & 0.118 & 0.852 & 3.182 & 0.004 \\
\hline
\end{tabular}

$\mathrm{R}^{2}=0.395 ; \mathrm{F}=6.87 ;$ probability $=0.002$

$$
E B I T D A / N S=c+1.103 F_{3}+0.640 F_{1}^{2}+0.852 F_{2} F_{3}(3)
$$

When we interpret the equation we see that as brand knowledge (F1) increases EBITDA/NS ratio also increases exponentially.

Loyalty's (F2) effect on EBITDA/NS changes with the sign of Perceived Quality (F3). If a firm has low perceived quality, F2 acts negatively on this financial performance indicator. On the contrary, if a firm has high perceived quality, F2 acts positively on EBITDA/NS.

$$
\frac{\partial E B I T D A / N S}{\partial F_{3}}=+1.103+0.852 F_{2} \text { (4) }
$$

In all cases tested in the study, improving F3 (Perceived Quality) led to an (exponential) increase in EBNS (thus better financial performance). Dependence on F2 affects not the sign but magnitude of the relationship between F3 and EBNS ratio, as can be seen in the Equation 4.

Increasing the perceived quality for firms with low loyalty leads to a low magnitude positive effect on EBITDA/NS performance indicator. On the other hand the firms with high loyalty enjoy a high magnitude positive effect on this performance indicator when the perceived quality is improved.

As indicated before, all of the findings of this study illustrating the relationships between three CBBE factors and all the financial performance indicators are presented in Appendix 1.

As an outcome of the study in general we can say that there are statistically significant relationships between $\mathrm{CBBE}$ factors and all financial performance indicators excluding financial leverage ratio. F1 has a significant positive effect on 8 of the 11 financial performance indicators analyzed. Seven of these effects are exponential, one is linear. F2 on the other hand affects only about half of the financial performance indicators tested. Finally F3 affects most of the financial performance indicators except ROS (Return on Share) and financial leverage ratio. F3 affects financial performance indicators more strongly on average than the other two factors.

In addition, it is seen that the way CBBE factors act on financial performance indicators change at certain threshold levels of brand equity factor scores. 
To better understand the CBBE factors' effect on different aspects of financial performance, the indicators are grouped and the findings for each group are presented separately below.

Results of the regression analysis between the CBBE factors and the financial indicators that are grouped in overall financial performance (ROS, FV/BV, P/S) reveal that improvement of all three factors leads to better overall financial performance. When the strength of the effects was analyzed, F1 appeared to be the most important factor followed by F3 and lastly F2.

Indicators in profitability group (NPM, EBITDA/NS, ROA) can be defined as profitability and also the ability to use sources effectively. After analyzing the relationships between the CBBE factors and indicators in this group, F3 (Perceived Quality) is seen as the factor that affects the highest number of indicators. F1 (Knowledge) and F2 (Loyalty) dimensions can be considered equally important.

When the financial indicators grouped under the size of operations (Net Sales, Market Value, Operational Income) are analyzed the effects of F1 and F3 come forth as the dominant factors. The secondary factor that affects this group of financial performance indicators surfaces as F2.

Current ratio and financial leverage ratio were used to analyze the financial strength of the company. The relationship between the CBBE factors and financial leverage ratio was insignificant. On the other hand current ratio was affected negatively by F2 and F3. This can be considered natural because as a company's brand equity increases it can utilize more financial resources (open more credit lines from banks etc.) and can carry more debt, thus a higher current ratio.

\section{CONCLUSIONS}

As for managerial implications, perceived quality appears to be the primary dimension of CBBE that should be improved upon for enhancing financial performance. The second factor that should be taken into account is the knowledge factor that appeared as the composite of brand awareness and brand association components. The least important factor among the three is seen as brand loyalty.

When we interpret the analysis results on a factor basis we can see that awareness and associations composite factor is the most important factor that affects the size of operations. Higher awareness among the general populace provides a larger potential market for the firm. On the other hand, knowledge factor did not affect the current ratio of the firm, which leads us to the conclusion that awareness among the populace does not offer any advantages in terms of debt carrying or paying ability. Profitability was mainly related to the perceived quality factor. Brands perceived as offering higher quality products can benefit from premium pricing and higher profit margins, which were confirmed in this analysis.

From a managerial perspective it should be easier to improve loyalty after reaching a particular awareness level and a certain degree of quality level is established among 
consumers. The improvements in the perceived quality of a brand provide a solid base on which to develop. Well-known firms with high awareness but low perceived quality (products) may have trouble performing well financially.

Another interesting finding is the need to improve the CBBE to a certain degree to be able to reap the financial benefits. Until a threshold point, improvements in CBBE factors may not lead to improved financials. This can be explained as the resources needed to improve these dimensions are quite significant until the brand acquires a certain degree of awareness or an acceptable level of perceived quality among customers. As firms establish and reach above these thresholds in brand equity dimensions, they finally start to reap the financial benefits and their financial performance indicators begin to improve quickly.

\section{LIMITATIONS \& FUTURE RESEARCH AVENUES}

The study carried out has some limitations in different dimensions. For instance, firms from a wide variety of sectors are included in the study to be representative of consumer markets, however firms from banking and financial services sectors that have unique financial statements and financial performance indicators were omitted from the study. Due to the unavailability of reliable and comparable financial data in addition to the potential bias of their global marketing and promotional activities on the consumer based study, the multinational firms were also omitted. Accordingly it was not possible to select firms from all major consumer sectors that comprise the consumer economy of Turkey. Extending the findings directly to businesses from different sectors with different dynamics may lead to unreliable conclusions.

The field study was carried out only once. Answers to the questions in the survey may be affected positively or negatively from contemporary developments and messages in the media regarding the brands covered in the study. Also promotional and communicational activities originating from the brands' may have affected the results.

In the analysis brand awareness and brand associations converged into one dimension as experienced by Yoo and Donthu (2001), which the proposed model is primarily based on. These two constructs are conceptually defined as separate concepts in the literature (Aaker 1991; Keller 1993). Consumers may be aware of a brand however they may not know it well or have experienced it enough, or are not interested in it to develop a set of associations with it. To be able to measure brand associations for different industries, a large set of possible brand associations, a significant number of questions should be used in the questionnaire which was not feasible in this study.

The scope of the study in terms of the number of the brands and industries covered may be increased. The brands that have different target consumer segments and different financial structures should be analyzed to be able to generalize findings of this study.

Increasing the geographical reach and then carrying out the survey again will definitely help in verifying and increasing the reliability of the findings. Researchers are encouraged to repeat the study in different regions and countries. 
The repetition of this study in different time frames will help improve the representativeness of the study and to decrease influences of external effects mentioned in the limitations sections.

The moderating effects of demographics or brand/category experience were not tested in this paper. These and similar factors may affect relations between CBBE constructs and financial performance. For instance, in terms of brand loyalty, if a consumer has no or limited experience with a category or brand he or she may not be able to develop any loyalty towards it.

\section{Acknowledgements}

This study was sponsored by Istanbul Chamber of Industry (ICI) in scope of the academic researcher support program "Industry Support for Doctorate and Graduate Thesis Program between ICI and ITU”. 


\section{REFERENCES}

- $\quad$ Aaker, D.A., (1991), Managing Brand Equity, The Free Press New York, NY.

- Aaker, D.A., (1996), "Measuring Brand Equity Across Markets Products", California Management Review 38(3), 102-120.

- $\quad$ Aaker, D.A. and Keller, K.L. (1990), "Consumer evaluations of brand extensions", Journal of Marketing 54(1), 27-41.

- $\quad$ Aaker, D.A. and Jacobson, R. (1994), "The Financial Information Content of Perceived Quality”, Journal of Marketing Research 31(2), 191-201

- $\quad$ Agarwal, M.K., Rao, V.R. (1996), “An Empirical Comparison of Consumer-Based Measures of Brand Equity", Marketing Letters 7(3), 237-247

- Ambler, T. (2003) Marketing and the Bottom Line: Creating the Measures of Success. Financial Times/Prentice Hall, London, UK.

- $\quad$ Bendixen, M., Bukasa, K.A., Abratt R. (2004), "Brand equity in the business-tobusiness market" Industrial Marketing Management 33(5), 371- 380

- $\quad$ Biel, A.L., (1992). "How Brand Image Drives Brand Equity", Journal of Advertising Research 32(6), 6-12.

- $\quad$ Bottomley, P.A. and Doyle, J.R. (1996), "The formation of attitudes towards brand extensions: testing and generalising Aaker and Keller's model", International Journal of Research in Marketing 13(4), 365-377.

- $\quad$ Buil, I., de Chernatony, L. and Martinez, E. (2008), “A cross-national validation of the consumer based brand equity scale", Journal of Product and Brand Management 17(6), 384-392.

- Chaudhuri, A. and Holbrook, M. B. (2001), "The chain of effects from brand trust and brand affect to brand performance: The role of brand loyalty", Journal of Marketing 65(2), 81-93.

- $\quad$ Chang, H. H. and Liu, Y. M. (2009). The Impact of Brand Equity on Brand Preference and Purchase Intentions in the Service Industries. The Service Industries Journal 29(12), 1687.

- Chen, A.C. (2001), "Using free association to examine the relationship between the characteristics of brand associations and brand equity", Journal of Product \& Brand Management 10(7), 439-451. 
- Christodoulides, G. and de Chernatony L. (2010), "Consumer-based brand equity conceptualisation and measurement", International Journal of Market Research 52(1), 43-66

- $\quad$ Cobb-Walgren, C.J., Ruble, C.A. \& Donthu N. (1995), "Brand equity, brand preference, and purchase intent", Journal of Advertising 24(3), 25-40.

- Davis, S.M. (2000), Brand Asset Management. Jossey-Bass, San Francisco, CA.

- $\quad$ de Chernatony, L. and McWilliam G. (1989), "The varying nature of brands as asset", International Journal of Advertising 8(4), 339-349.

- $\quad$ Dodds, W.B., Monroe, K.B., Grewal, D. (1991), "Effects of price, brand, and store information on buyers' product evaluation", Journal of Marketing Research 28, 307-319.

- $\quad$ Erdem, T., Swait, J. and Louviere, J. (2002), "The impact of brand credibility on consumer price sensitivity", International Journal of Research in Marketing 19(1), 1-19.

- Farquhar, P.H., (1989). "Managing Brand Equity", Journal of Marketing Research, September, 24-33.

- $\quad$ Farquhar, P.H., Han J.Y and ljiri Y. (1991), "Recognizing and Measuring Brand Assets", Marketing Science Institute, Cambridge, MA pp. 91-119.

- Feldwick, P. (1995), "What is brand equity anyway, and how do you measure it?" Journal of the Market Research Society 38(2), 85-104.

- Hankinson, G. A. and Cowking, P. (1993), Branding in Action, McGraw-Hill, Maidenhead.

- Howard, Steven, (1998), Corporate Image Management, ButterworthHeinemann, Singapore p.30.

- Hsin Hsin, C., \& Ya Ming, L. (2009), "The impact of brand equity on brand preference and purchase intentions in the service industries", The Service Industries Journal 29(12), 1687-1706.

- Jones, T. and Taylor, S.F. (2007), "The conceptual domain of service loyalty: how many dimensions?", Journal of Services Marketing, 21(1), 36-51 
- Jones, Tim, Shirley F. Taylor, and Harvir S. Bansal (2008), "Commitment to a Friend, a Service Provider, or aService Company-Are They Distinctions Worth Making?", Journal of the Academy of Marketing Science 36(4), 473-487.

- $\quad$ Kapferer, J.N., (1992), Strategic Brand Management, The Free Press, New York, NY.

- Kamakura WA, Russell GJ., (1993), "Measuring brand value with scanner data", International Journal of Research in Marketing 10(1), 9-21.

- $\quad$ Keller, K.L., (1993), Conceptualizing, Measuring, and Managing Customer-Based Brand Equity, Journal of Marketing, 57(1), 1-22.

- $\quad$ Keller, K.L., and Lehmann, D. (2003) "How do brands create value?" Marketing Management, (May-June) 27-31

- Kotler, P. and Keller K.L., (2006), Marketing Management, 12th edition, Prentice Hall, NJ.

- Krishnan, H.S., (1996), “Characteristics of memory associations: a consumer based brand equity Perspective", International Journal of Research in Marketing, 13(4), 389-405.

- Kumar V., Shah D., Venkatesan R. (2006), “Managing Retailer Profitability-One Customer at a Time", Journal of Retailing 82(4), 277-294.

- Kumar, V. and Reinartz, W. (2006), Customer Relationship Management: A Databased Approach. John Wiley, New York, NY.

- $\quad$ Lassar, W., Mittal, B. and Sharma, A., (1995), "Measuring Customer Based Brand Equity", Journal of Consumer Marketing 12(4), 11-19.

- Mackay, M.M. (2001), "Evaluation of brand equity measures: further empirical results", The Journal of Product and Brand Management 10(1), 38-51.

- Martin, G.S. and Brown, T.J.(1991), "In Search of Brand Equity: The Conceptualization and Operationalization of the Brand Impression Construct", Winter Educator's Conference Proceedings, Terry L. Childers et al. eds. Chicago: American Marketing Association, 431-438.

- Mizik, N. and Jacobson, R. (2008), "The financial value impact of perceptual brand attributes", Journal of Marketing Research, 45(1), 15-32. 
- Moorman, C., \& Rust, R. T. (1999). The role of marketing. Journal of Marketing, 63, 180-197.

- Motameni, R. and Shahrokhi, M., (1998), "Brand Equity Valuation A Global Perspective", Journal of Product and Brand Management, 7(4), 275-290.

- $\quad$ Okazaki, S. and Taylor, S. (2008) "What is SMS advertising and why do multinationals adopt it? Answers from an empirical study in European markets" Journal of Business Research 61(1), 4-12

- Oliver, R.L., (1997), Satisfaction: A Behavioral Perspective on the Consumer, New York, McGraw-Hill.

- Pappu, R., Quester, P.G. and Cooksey, R.W. (2005), “Consumer-based brand equity: improving the measurement - empirical evidence". Journal of Product and Brand Management, 14(3), 143-154.

- $\quad$ Park, C.S. and Srinivasan, V., (1994), "A Survey Based Method for Measuring and Understanding Brand Equity", Journal of Marketing Research 31, 271-288.

- $\quad$ Pitta, D.A. and Katsanis, L.P. (1995), "Understanding brand equity for successful brand extension", Journal of Consumer Marketing 12(4), 51-64

- Prasad, K. and Dev, C.S., (2000), Managing Hotel Brand Equity: A Customercentric Framework for Assessing Performance, Cornell Hotel and Restaurant Administration Quarterly, Vol. June, pp. 22-31.

- $\quad$ Rangaswamy, A., Burke, R.R. and Oliva, T.A. (1993), Brand equity and the extendibility of brand names. International Journal of Research in Marketing 10(1), 61-75.

- $\quad$ Rossiter, J.R. and Percy, L. (1987), Advertising and Promotion Management, New York, NY: McGraw Hill.

- $\quad$ Senthilnathan, S., \& Tharmi, U. (2012), "The Relationship of Brand Equity to Purchase Intention". IUP Journal of Marketing Management, 11(2, pp. 7-26.

- $\quad$ Shocker, A.D., and Weitz, B., (1988), "A perspective on brand equity principles and issues", Leuthesser L, editor. Report No: 88-104. Cambridge, Marketing Science Institute, 2-4.

- Smith, D.C. and Park, W. (1992), "The Effect of Brand Extensions on Market Share and Advertising Efficiency. Journal of Marketing Research 29, 296-313. 
- Simon, C.J., and Sullivan, M.W., (1993), "The Measurement and Determinants of Brand Equity a Financial Approach", Marketing Science 12(1), 28-52.

- Srinivasan, V. (1979), "Network models for estimating brand specific effects in multi-attribute marketing models", Management Science, 25(1), 11-25.

- $\quad$ Srivastava, R. and Shocker, A.D. (1991), "Brand equity: a perspective on its meaning and measurement", Report Number 91-124. Cambridge, Marketing Science Institute.

- Yoo, B., Donthu, N., Lee, S. (2000), “An examination of selected marketing mix elements and brand equity", Journal of the Academy of Marketing Science, Vol. 28(2), 195-211.

- Yoo, B., and Donthu, N. (2001), "Developing and validating a multidimensional consumer-based brand equity scale", Journal of Business Research 52(1), 1-14.

- Washburn, J.H. and Plank R.E. (2002), "Measuring brand equity: an evaluation of a consumer-based brand equity scale", Journal of Marketing Theory and Practice, 10(1), 46-62.

- Zeithaml, V.A. (1988), "Consumer perceptions of Price, Quality, Value: a means end model and synthesis of evidence", Journal of Marketing 52, 2-22.

- Zimmermann, R. (2001), Brand Equity Excellence Volume 1: Brand Equity Review, BBDO Group, Düsseldorf. 


\section{APPENDIX 1: EFFECT OF BRAND EQUITY FACTORS ON THE FINANCIAL PERFORMANCE INDICATORS}

\begin{tabular}{|c|c|c|c|c|c|c|c|c|c|c|c|c|}
\hline Financial Indicator & F1 & F2 & F3 & $F 1^{2}$ & $F 2^{2}$ & $\mathrm{F3}^{2}$ & F1F2 & F1F3 & F2F3 & $R^{2}$ Adj. & $\mathbf{F}$ & sig. \\
\hline ROS & & & & $0.406^{* *}$ & & & & & & 0.133 & 5.145 & $0.032^{* *}$ \\
\hline Firm/Book Value & $0.329^{*}$ & $0.527^{* *}$ & $-1.101^{* * *}$ & & & & $0.709^{* * *}$ & $-0.878^{* * *}$ & $-1.17^{* * *}$ & 0.504 & 5.571 & $0.001^{* *}$ \\
\hline Price/Sales & & & $0.571^{* *}$ & $0.583^{* * *}$ & & $0.581^{* *}$ & & & & 0.227 & 3.650 & 0.027 \\
\hline Net Profit Margin & & & $0.004^{* * *}$ & & & $0.040^{* *}$ & & & & 0.235 & 5.141 & $0.013^{* *}$ \\
\hline EBITDA/Net Sales & & & $1.003^{* * *}$ & $0.640^{* * *}$ & & & & & $0.852^{* * *}$ & 0.395 & 6.868 & $0.002^{* *}$ \\
\hline Return On Assets & & & $0.333^{*}$ & & & & & & & 0.077 & 3.248 & $0.083^{*}$ \\
\hline Current Ratio & & $-0.578^{* * *}$ & & & $0.714^{* * *}$ & $-1.477^{* * *}$ & & & $0.698^{*}$ & 0.297 & 3.855 & 0.015 \\
\hline Oper. Income & & & $1.102^{* * *}$ & $0.591^{* * *}$ & & & & & $0.932^{* * *}$ & 0.406 & 7.139 & $0.001^{* * *}$ \\
\hline Net Sales & $0.699^{* * *}$ & & $0.273^{* *}$ & $0.416^{* * *}$ & & & & & & 0.624 & 15.951 & $0.000^{* * *}$ \\
\hline Market Value & $0.578^{* * *}$ & & & $0.318^{* *}$ & & & & $0.362^{* *}$ & & 0.393 & 6.820 & $0.002^{* * *}$ \\
\hline
\end{tabular}

${ }^{*}$ Significant at 10 per cent level; ${ }^{* *}$ Significant at 5 per cent level; ${ }^{* * *}$ Significant at 1 per cent level. 